\title{
Non-essential ribosomal proteins in bacteria and archaea identified using COGs
}

\author{
Michael Y. Galperin*, Yuri I. Wolf, Sofya K. Garushyants, Roberto Vera Alvarez, \\ and Eugene V. Koonin*
}

\begin{abstract}
National Center for Biotechnology Information, National Library of Medicine, National Institutes of Health, Bethesda, Maryland 2094, USA
\end{abstract}

*To whom correspondence should be addressed: galperin@ncbi.nlm.nih.gov;
koonin@ncbi.nlm.nih.gov

ORCID:

Michael Y. Galperin, 0000-0002-2265-5572

Yuri I. Wolf, 0000-0002-0247-8708

Sofya K. Garushyants, 0000-0003-2104-1795

Roberto Vera Alvarez, 0000-0002-4108-5982

Eugene V. Koonin, 0000-0003-3943-8299 


\section{ABSTRACT}

2 Ribosomal proteins (RPS) are highly conserved across the bacterial and archaeal 3 domains. Although many RPs are essential for survival, genome analysis demonstrates

4 the absence of some RP genes in many bacterial and archaeal genomes. Furthermore, 5 global transposon mutagenesis and/or targeted deletion showed that elimination of 6 some RP genes had only a moderate effect on the bacterial growth rate. Here, we 7 systematically analyze the evolutionary conservation of RPs in prokaryotes by compiling 8 the list of the ribosomal genes that are missing from the one or more genomes in the 9 recently updated version of the Clusters of Orthologous Genes (COG) database. Some of 10 these absences occurred because the respective genes carried frameshifts, presumably, 11 resulting from sequencing errors, while others were overlooked and not translated 12 during genome annotation. Apart from these annotation errors, we identified multiple 13 genuine losses of RP genes in a variety of bacteria and archaea. Some of these losses are 14 clade-specific, whereas others occur in symbionts and parasites with dramatically 15 reduced genomes. The lists of computationally and experimentally defined non16 essential ribosomal genes show a substantial overlap, revealing a common trend in 17 prokaryote ribosome evolution that could be linked to the architecture and assembly of 18 the ribosomes. Thus, RPs that are located at the surface of the ribosome and/or are 19 incorporated at a late stage of ribosome assembly are more likely to be non-essential 20 and to be lost during microbial evolution, particularly, in the course of genome 21 compaction. [237 words]

\section{IMPORTANCE}

In many prokaryote genomes, one or more ribosomal protein (RP) genes are missing. Analysis of 1,309 prokaryote genomes included in the COG database shows that only about half of the RPs are universally conserved in bacteria and archaea. In contrast, up to 21 other RPs are missing in some genomes, primarily, tiny $(<1 \mathrm{Mb})$ genomes of host-associated bacteria and archaea. Ten universal and nine archaea-specific ribosomal proteins show clear patterns of lineage-specific gene loss. Most of the RPs that are 
30 frequently lost from bacterial genomes are located on the ribosome periphery and are

31 non-essential in Escherichia coli and Bacillus subtilis. These results reveal general trends

32 and common constraints in the architecture and evolution of ribosomes in prokaryotes.

33 [117 words]

INTRODUCTION

Ribosomes are macromolecular cell factories that consist of rRNAs and ribosomal proteins (RPs) and are responsible for the translation of all mRNAs. Bacterial ribosomes that have been thoroughly characterized in model organisms, such as Escherichia coli and Bacillus subtilis, typically contain 54 core RPs, 33 in the large subunit and 21 in the small subunit (1-5). Archaeal ribosomes include up to 66 proteins, of which 33 are universal, i.e. shared with bacteria and eukaryotes (18 in the large ribosomal subunit and 15 in the small subunit), and 33 proteins are shared only with eukaryotes. The list of core RPs in several model organisms is provided in Supplementary Table S1.

Several lines of evidence indicate that some RPs can be non-essential, at least, in some organisms and under certain conditions. First, experiments on genome-wide mutagenesis have resulted in the generation of mutants with a deletion or transposon insertion in a variety of RP genes. Such mutants were viable, albeit grew slower than the wild type $(6,7)$. Such experiments have been performed in a wide variety of bacteria, albeit, so far, not in archaea. The global mutagenesis approach has some potential 50 caveats, such as conditional lethality (mutations in two genes may be tolerated 51 individually but not together) and functional compensation by paralogs. For example, $E$. 52 coli encodes paralogs of L31 and L36, whose expression can suppress the lack of these 53 RPs (8). Similarly, B. subtilis encodes two paralogs of L31, L33, and S14 each that could 54 partly compensate for the loss of the respective RP function $(9,10)$. In addition, the 55 absence of certain RP genes can be compensated by changes in the intracellular milieu, 56 such as, for example, high level of $\mathrm{Mg}^{2+}$ ions $(11,12)$. Gene essentiality data derived 
57 from genome-wide mutagenesis studies are well represented in the literature and are 58 also available in such online databases as the Database of Essential Genes [DEG, (13)] 59 and the Online Gene Essentiality database [OGEE, (14)]. In addition to the global 60 mutagenesis studies, data on gene essentiality have been obtained by monitoring the 61 effects of suppressing gene expression, e.g. with antisense RNA (15-17).

Another general approach to the prediction of (non)essential RPs is by using comparative genomics (1-5). The absence of a particular gene in a complete microbial genome (or, better yet, in several related genomes) strongly suggests that this gene is non-essential, at least for growth on a rich medium. This approach also has several caveats, such as the problems with genome completeness and sequencing quality, as well as the presence of paralogs or other forms of functional compensation. However, it is cheap, high-throughput, and readily applies to hard-to-grow and even non-cultured bacteria and archaea. Genome comparisons have proved particularly fruitful for the analysis of the highly reduced genomes of intracellular parasites, insect cell symbionts,

71 and for the near-minimal genomes of axenically-growing mollicutes (18-25). Collectively, 72 these studies suggest that the number of truly essential RP genes could be as small as 33 73 (21).

The universal presence of most RPs in organisms from all three domains of life makes them a key component of the small set of highly conserved genes that can be used for the construction of deep-rooted phylogenetic trees and the global Tree of Life

$77(4,26,27)$. Therefore, understanding the evolution of RPs and differentiating universal, essential RPs from dispensable ones that are occasionally lost during evolution is an important task in evolutionary biology.

Here, we report the patterns of presence and absence of RP genes in the current 81 release of the Clusters of Orthologous Genes (COGs) database (28). The COG database is 82 a particularly convenient tool for the analysis of gene gain and loss because it includes a 83 limited number of high-quality complete microbial genomes and features COG-specific 
84 patterns of presence and absence of evolutionarily conserved genes in the respective

85 organisms (29-31). In addition, the COG construction algorithm $(32,33)$ provides for the

86 detection of even highly diverged orthologous proteins that are not necessarily

87 recognized as orthologs by other tools $(30,31,34,35)$. Phyletic patterns of COGs have

88 been previously used to reconstruct the ancestral states and evolution of various

89 functional systems including the minimal and ancestral sets of RPs $(2,36)$. Owing to

90 these features, the COG database allows for straightforward identification of the

91 genomes that do not encode the given RP.

92 The current version of the COG database (28) features a selection of COGs grouped 93 by metabolic pathways and functional complexes, including the RPs of the 50S and 30S

94 ribosome subunits as well as a group of archaea-specific RPs. Examination of the 95 phyletic patterns of the COGs for all three groups allowed us to (i) compile the list of 96 about 500 RP genes missing in some bacterial and/or archaeal genomes (some actually 97 lost and some missing because of sequencing problems); (ii) identify more than 50 RP 98 genes that have been overlooked in the course of genome annotation, and (iii) establish 99 the patterns of RP gene loss during bacterial and archaeal evolution, and iv) correlate 100 the experimentally-derived and computationally-generated sets of the likely non101 essential RP genes.

\section{RESULTS}

104 The conserved ribosomal protein (RP) set, extracted from the current release of 105 the COG database (28), consisted of 54 core RPs: 33 from the 50S subunit (L1-L7/L12, 106 L9-L11, L13-L25, and L27-L36) and 21 (S1-S21) from the 30 S subunit (1-5). Several 107 additional proteins, such as S22 (RpsV, Sra) and S31e (Thx), which are associated with 108 ribosomes in some bacteria $(37,38)$, are not covered in the COG database and have not 109 been included in the analyzed set. The archaeal RP gene set included 66 genes, of which 11033 are shared with bacteria and eukaryotes (18 in the large ribosomal subunit and 15 in 
111 the small subunit), and 33 RPs that are shared only with eukaryotes. The list of of core

112 RPs from model organisms such as Escherichia coli K-12, Bacillus subtilis strain 168,

113 Mycoplasma pneumoniae M129, Aeropyrum pernix K1, and Haloarcula marismortui

114 ATCC 43049, that were analyzed here is presented in Supplementary Table S1. This table

115 shows that the archaea-specific RP set is quite variable: $A$. pernix encodes seven RPs

116 that are missing in H. marismortui.

\section{Frameshifted and unannotated ribosomal protein genes}

118 Before analyzing the patterns of RP loss across the diversity of bacteria and 119 archaea, it was necessary to identify and eliminate artifacts that could result from 120 sequencing or annotation errors. To ensure the quality of the genome collection, 121 members of the International Nucleotide Sequence Database Collaboration, the DNA 122 Database of Japan, EBI's European Nucleotide Archive, and NCBI's GenBank, routinely 123 check new genome submissions for the presence of certain RPs (39). Nevertheless, due 124 to the sheer number of sequenced genomes, errors occasionally crop up, which 125 becomes evident when the same organisms repeatedly show up as missing certain RPs

126 despite having relatively large genomes and in the absence of similar problems in 127 related organisms. Another tell-tale sign of sequencing problems is the presence of

128 frameshifted genes that are present in a full-length form in other members of the same

129 lineage (Table S2). There are good reasons to suspect that many if not most of these 130 frameshifts represent sequencing errors, rather than genuine mutations or cases of

131 programmed translational frameshifting that is not known to be a common mechanism 132 of RP translation (40). For example, the 6.09-Mb genome of the betaproteobacterium

133 Mitsuaria sp. str. 7 misses the genes for L13, L21, L25, L27, and S9 proteins, which is 134 unique among the genomes of this size. Likewise, the 3.97-Mb genome of the 135 alphaproteobacterium "Candidatus (Ca.). Filomicrobium marinum $Y$ " lacks the L1, $136 \mathrm{~L} 7 / \mathrm{L} 12, \mathrm{~L} 10, \mathrm{~L} 11, \mathrm{~S} 7$, and S12 genes (Table S2) and is the only genome where the genes 137 for the latter two proteins are missing. 
Another widespread cause of missing RPS is the automated genome annotation, which sometimes fails to recognize genuine protein-coding genes, particularly short ones. As a result, these overlooked ORFs are not included in the respective protein sets.

141 Sequencing and annotation problems often show up in the same genomes, making their 142 quality suspect and putting into question the apparent absence of certain RPs. As an 143 example, in the 4.28-Mb GenBank entry for the halophilic gammaproteobacterium 144 Salinicola tamaricis F01, rplF (encoding the L6 protein), rpll (L9), rp/L (L7/L12), rp/Y (L25), 145 and $\operatorname{rps} D(\mathrm{~S} 4)$ genes are frameshifted, the $\operatorname{rps} B(\mathrm{~S} 2)$ gene is absent, and two full-length 146 genes, $r p / D$ (L4) and $\operatorname{rps} R$ (S18), are present but have been overlooked in the course of 147 genome annotation. Similarly, the current GenBank entry for Sulfobacillus acidophilus 148 str. TPY, a member of the Clostridia, lacks the genes for RPs L27, L28, L32, L33, L36, and 149 S14, which are encoded in the genome but have been overlooked in course of 150 annotation. These genes have been easily found by the TBLASTn search (41) using the 151 respective RPs from closely related clostridial genomes as queries (see Table S3 for 152 details). Two more organisms, Pelotomaculum thermopropionicum and "Ca. Methylo153 mirabilis oxyfera", had five overlooked ribosomal genes each (Table S3). Two or more 154 unannotated RP genes were found in seven more bacterial genomes.

155 The tiny (606-kb) genome of the nanoarchaeon "Ca. Nanopusillus acidilobi" 156 presented a different problem. The current protein set of "Ca. Nanopusillus acidilobi" in

157 GenBank misses 14 RPs that are found in almost all other archaeal genomes. However, a 158 detailed examination of this genome showed that only four RP genes were truly missing 159 (Table 1), the gene encoding S14 protein was frameshifted (Table S2), and the gene for 160 L37e has been overlooked and could be found by TBLASTn (Table S3). Full-length ORFs 161 coding for eight other RPs: L6p/L9e (genomic locus tag Nps_02895), L15e (Nps_01385), 162 L16/L10ae (Nps_03305), L22 (Nps_03365), L24 (Nps_02910), L35ae (Nps_03205), S6e 163 (Nps_01880), and S15p/S13e (Nps_01520), were correctly identified at the annotation 164 stage and described in the respective publication (42). However, for some unknown 165 reason, these genes were assumed to be disrupted and were erroneously marked as 166 pseudogenes in the GenBank entry for "Ca. Nanopusillus acidilobi" (see Table S3 for 
167 details). As a result, the RPs encoded by these genes, which are all longer than 110

168 amino acids, never made it into the protein database. The same problem on a lesser

169 scale was observed for the other nanoarchaeon in the current COG collection,

170 "Nanohaloarchaea archaeon SG9", where the genes for L24e, L40e, and S28e proteins

171 were overlooked, whereas genes encoding L18 and S2 were marked as pseudogenes

172 and left untranslated (Table S3). Correcting such annotation problems is important for

173 assessing the essentiality of RPs in biologically interesting but poorly studied groups of

174 microorganisms.

\section{Loss of ribosomal protein genes in tiny genomes}

176 Several previous studies investigated the gene contents in organisms with small 177 genome sizes and reported a widespread absence of certain RP genes $(2,21,25,43)$.

178 The most extensive loss of RP genes was observed in the tiny genomes of obligate insect 179 symbionts that include members of Alphaproteobacteria, Betaproteobacteria, and

180 Bacteroidetes. These genomes have undergone a dramatic compaction, resulting in 181 genome sizes of less than $1.0 \mathrm{Mb}$ and widespread loss of one or more RP genes $(21,25$, 182 45). Indeed, in some of these tiny genomes, the loss of RP genes was extensive, such 183 that up to $21 \mathrm{RP}$ genes could be missing (Table 1). A massive loss of RP genes was also 184 observed in the 593-kb genome of the bryozoan symbiont "bacterium AB1", which is

185 currently unclassified and apparently belongs to a novel major bacterial lineage (44).

186 However, not all bacteria with tiny genomes display massive loss of RP genes, and 187 indeed, some of them retain nearly all RPs. The 263-kb genome of the flavobacterium 188 "Ca. Uzinura diaspidicola", an endosymbiont of armored scale insects, misses only a 189 single RP gene, $r p m C$, that encodes L29 (Table 1). Similarly, the absence of $r p m C$, but no

190 other RP gene, was observed in another flavobacterium, "Ca. Walczuchella 191 monophlebidarum", which has a slightly larger 309-kb genome. The 641-kb genome of 192 yet another member of Bacteroidetes, Blattabacterium sp., also misses a single RP gene,

193 in this case, the L30-encoding rpmD. The $r p m D$ gene is also the only one missing in the 
194 genomes of the alphaproteobacterium Neorickettsia sennetsu (859 kb) and in some 195 gammaproteobacteria, such as "Ca. Portiera aleyrodidarum" (357 kb), "Ca. Riesia 196 pediculicola" (582 kb), and "Ca. Blochmannia pennsylvanicus" (792 kb). The 837-kb 197 genome of "Ca. Fokinia solitaria", an obligate intracellular endosymbiont of the 198 ciliate Paramecium sp., lacks the genes for both L29 and L30 (Table 1).

199 Some tiny genomes actually encode the full set of core RPs (Figure 1A). In the 200 investigated genome set, the smallest such genome $(353 \mathrm{~kb})$ was from the 201 gammaproteobacterial symbiont of mealybugs "Ca. Mikella endobia". This bacterium 202 inhabits the cytoplasm of the betaproteobacterium "Ca. Tremblaya princeps", which has 203 an even smaller (171 kb) genome (45) and lacks the genes for eight RPs (Table 1). Other 204 insect endosymbionts with tiny genomes that encode the full set of RPs include the 205 alphaproteobacterial psyllid symbiont "Ca. Profftella armatura" (465 kb) and the 206 gammaproteobacteria "Ca. Purcelliella pentastirinorum" and "Ca. Moranella endobia" 207 (genome sizes, $480 \mathrm{~kb}$ and $539 \mathrm{~kb}$, respectively, Table 2). The latter organism is also an 208 intracellular symbiont of "Ca. Tremblaya princeps" (45).

209 All 122 archaeal genomes included in the COG database lack 21 bacteria-specific 210 RPs: L9, L7/L12, L17, L19-L21, L25, L27, L28, L31-L36, S1, S6, S16, S18, S20, and S21 (1, 4, 211 5), see Table S1. Only five of these 122 archaeal genomes are smaller than $1.2 \mathrm{Mb}$ 212 (Figure 1B); three of these small genomes come from the DPANN superphylum, one 213 from Euryarchaeota, and one remains unclassified. These genomes show conservation 214 of all the universal RPs and most archaea-specific RP genes. Each of these five genomes 215 lacks the genes for L13e and S30, and in some of them, L20a/L18a and L39e genes are 216 missing as well (Table 1). As mentioned above, a substantial number of RPs, nine in "Ca. 217 Nanopusillus acidilobi" and five in "Nanohaloarchaea archaeon SG9", are encoded in the 218 respective genomes and are only missing in GenBank owing to the errors in genome 219 submission (Tables 1 and S3).

\section{Lineage-specific loss of ribosomal protein genes}


221 Figure $1 \mathrm{~A}$ shows that, at genome sizes over $1.5 \mathrm{Mb}$, bacterial genomes rarely lack 222 more than three RPs. At slightly larger genome sizes, most organisms contain the full RP 223 sets. The exact position of the boundary between RP-missing and RP-complete protein 224 sets varies between bacterial lineages but is typically around $2.0 \mathrm{Mb}$. The lowest such 225 boundary, $0.8 \mathrm{Mb}$, was detected in Gammaproteobacteria: the only gammaproteo226 bacterial genome in the COG that is larger than $0.8 \mathrm{Mb}$ but is missing any RP genes is the 227 above-mentioned genome of Salinicola tamaricis, where the absence of the rps $B$ gene is 228 likely due to a sequencing error. In the analyzed genome set, the boundary for 229 Betaproteobacteria and Chloflexi lies at $1.70 \mathrm{Mb}$, for Bacteroidetes at $1.88 \mathrm{Mb}$, for 230 Alphaproteobacteria at $2.01 \mathrm{Mb}$, whereas for Cyanobacteria it is $3.34 \mathrm{Mb}$.

231 Irrespective of the genome size, no RP gene loss was observed in any 232 representatives of the phyla Aquificae (9 genomes, $1.50-1.98 \mathrm{Mb}$ ), Chlamydiae (6 233 genomes, 1.04 - 3.07 Mb), Chlorobi (5 genomes, 2.15 - $3.29 \mathrm{Mb}$ ), Spirochaetes (11 234 genomes, $1.14-4.70 \mathrm{Mb}$ ), Synergistetes (5 genomes, $1.85-3.59 \mathrm{Mb}$ ), and the 235 proteobacterial class Epsilonproteobacteria (12 genomes, $1.64-3.19 \mathrm{Mb}$ ), covered in 236 the current version of COGs. Among poorly represented phyla (the "Other bacteria" 237 group in COGs), the full set of RP genes was found in both members of 238 Armatimonadetes, Gemmatimonadetes, and Ignavibacteriae and all three members of 239 Thermodesulfobacteria. Acidobacteria, Deltaproteobacteria, and Verrucomicrobia had a 240 single RP gene missing in a single organism, which could be due to the sequencing 241 problems.

242 In certain lineages, however, loss of ribosomal genes was consistently detected in 243 regular-sized genomes of free-living bacteria and archaea. As shown in Table 2, this type 244 of RP gene loss is often lineage-specific. A striking example is the previously reported 245 absence of the $\operatorname{rps} U$ (S21) gene in every member of the phylum Actinobacteria (4). This 246 trend still held true for the 155 actinobacterial genomes from 149 genera included in 247 the current version of the COG database. An additional check in the NCBI protein 248 database showed that S21 protein is not encoded in any genome from the phylum 
249 Actinobacteria sequenced to date. This protein is also missing in all representatives of

250 the phyla Deinococcus-Thermus, Fusobacteria, and Thermotogae (Table 2, see also Table

251 S3 in ref. (4)). All six representatives of the phylum Fusobacteria also lack the rp/Y (L25)

252 gene, which is absent in certain lineages of Actinobacteria, Firmicutes, and Tenericutes

253 as well (Table 2).

254 Similar lineage-specific patterns of gene loss were detected also in lower-level 255 taxa. Thus, in the clostridial order Halanaerobiales, five of the six members: 256 Acetohalobium arabaticum, Halanaerobium hydrogeniformans, Halobacteroides 257 halobius, Halocella sp. SP3-1, and Halothermothrix orenii, with genomes in the $2.5-4.0$ $258 \mathrm{Mb}$ range, lack rpmD (L30), rpmH (L34), and rpsU (S21) genes, whereas the remaining 259 member, Anoxybacter fermentans, only lacks the first two. No other clostridial member 260 in the COG system misses the $r p m H$ or rps $U$ genes, pinpointing the loss of these genes 261 to the base of the Halanaerobiales lineage. Likewise, in the order Lactobacillales (class 262 Bacilli), the rp/Y (L25) gene is lost in members of three families, Lactobacillaceae, 263 Leuconostocaceae, and Streptococcaceae, but present in the members of 264 Aerococcaceae, Carnobacteriaceae, and Enterococcaceae.

265 Among the Archaea, the L30e protein is missing in all representatives of the 266 euryarchaeal class Halobacteria and in all but one representative of the order 267 Thermoplasmatales (Table 2).

268 Widespread ribosomal protein gene loss in Mollicutes

269 The phylum Tenericutes presents a remarkable case of RP loss. Most early studies 270 of gene essentiality focused on Mycoplasma genitalium, which has a 580-kb genome, 271 the smallest among the known bacteria that are capable of axenic growth and can be 272 obtained in pure culture (the recently sequenced genomes of several strains of 273 M. genitalium are all at least $579.5 \mathrm{~kb}$ long) $(18,46)$. The genomes of $M$. genitalium and 274 its close relative Mycoplasma pneumoniae were found to lack $r p / Y$ (encoding L25 275 protein), $r p m D$ (L30) and $r p s A(S 1)$ genes. Genes for all other core RPs were present and, 
276 with the possible exception of $r p m B$ (L28), rpsT (S20) and rpmGB (encoding a paralog of

277 L33), none could be disrupted by transposon mutagenesis $(18,22,46)$.

278 Essentially the same pattern of the absence of the genes for L25, L30, and S1 has 279 been detected in other mollicutes as well $(21,43)$. In the current version of the COGs, 280 the coverage of this group was expanded to include representatives of 12 genera of 281 Mollicutes and two recently sequenced unclassified members of the phylum Tenericutes 282 (28). Among these 14 genomes, the genes for L25, L30, and S1 were missing, besides 283 Mycoplasma spp., in representatives of four other genera: Entomoplasma luminosum, 284 Mesoplasma florum, Spiroplasma chrysopicola, and Ureaplasma parvum. The genome of 285 "Ca. Hepatoplasma crinochetorum", in addition to these three genes, also lacked the 286 genes for L9 and S21, whereas in four other mollicutes, L25 and S1 were missing; two of 287 these genomes additionally lacked L35. Finally, the slightly larger (1.5-Mb) genome of 288 Acholeplasma laidlawii only lacked L25, whereas the two unclassified members of the 289 Tenericutes, "Ca. Izimaplasma str. HR1" and "Tenericutes bacterium MO-XQ" with their 290 even larger genomes (1.88 and $2.16 \mathrm{Mb}$, respectively) were found to encode the full set 291 of core RP genes.

\section{Experimentally identified non-essential ribosomal proteins}

293 Over the past 15-20 years, numerous studies have been published aiming at the 294 identification of the essential genes in a variety of bacteria (see Table S4). In the course 295 of these projects, many genes, including certain RP-encoding genes, were identified as 296 non-essential because their inactivation through transposon insertion or in-frame 297 deletion proved to be non-lethal. We reviewed the relevant literature and compiled the 298 lists of RP genes that have been successfully inactivated and therefore deemed non299 essential (Table S4). Table S4 shows that the lists of non-essential RPs can vary 300 dramatically between closely related organisms and, in some cases, even in experiments 301 performed by different groups on the same bacterial strains. It should be noted that 302 these lists include only the genes that have been explicitly reported to be disrupted. As 
303 an example, a detailed study of Bacteroides thetaiotaomicron strain VPI-5482 (47)

304 identified only two dozen essential RP genes, suggesting that others could have been

305 successfully inactivated. However, only mutants lacking L9 and L19 were used in

306 subsequent experiments, positively marking these proteins as non-essential for $B$.

307 thetaiotaomicron. Accordingly, numerous studies that centered on the essential genes

308 and did not report the details of the disruption of non-essential genes [e.g. ref. (48)

309 have been ignored. Nevertheless, a comparison of the data obtained on a variety of

310 distinct organisms clearly shows that certain RPs are far more likely to be non-essential

311 than the rest of the set. Furthermore, thorough analyses performed in $E$. coli and $B$.

312 subtilis $(6,7,49,50)$ have resulted in closely similar lists of non-essential RPs (Tables S1

313 and S4).

314 Loss propensity vs. non-essentiality of ribosomal proteins

315 Tables 1 and 2 show that certain RP genes are repeatedly identified as being prone

316 to be lost in a variety of bacteria and archaea. Notably, some of the same genes could

317 be successfully deleted in different organisms (Tables S1 and S4). Indeed, a comparison

318 of the data in Tables 1, 2, and S4 reveals a consistent pattern: the genes that are often

319 missing in tiny genomes are also non-essential in E. coli and/or B. subtilis (Table 3).

320 Conversely, the genes that are always found even in tiny bacterial genomes could not be

321 deleted from E. coli and, with the sole exception of L15, from B. subtilis (Table 3). Table

322 S1 also shows that 12 genes that are dispensable in E. coli and/or B. subtilis are bacteria-

323 specific, that is, missing in archaea and yeast. Indeed, the list of 26 dispensable RP genes

324 (Table 3), includes 16 (of 21) bacteria-specific RPs and 10 (of 33) universal RPs. Thus,

325 bacteria-specific RPs appear more likely to be non-essential than universal ones.

326 We are unaware of systematic efforts on disruption or deletion of archaeal RPS.

327 However, Table 2 shows that of the 33 archaea-specific RPs, 22 are conserved in nearly

328 all analyzed genomes, whereas the rest exhibit lineage-specific gene losses. 
It is instructive to compare the pattern of RP loss during prokaryote evolution with 331 the location of the respective RPS in the ribosome structure (51-56) and a related

332 characteristic, the order of RP joining during the ribosome assembly (3, 57-61). Figure 2 333 and Table S5 show that neither of these features provides a clear-cut prediction of the 334 RP loss propensity and/or (non)essentiality. Indeed, such frequently lost bacterial RPs as 335 L9, L25, L29, L30, and S21 are located on the surface of the ribosome (Fig. 2A,B). 336 However, L32, which is lost in many tiny genomes, has a significant buried area, whereas 337 L34, which is lost in two bacterial lineages, is mostly buried in the ribosome structure. 338 Conversely, several other surface RPs with relatively small buried areas (L16, L27, S16, 339 S17, S18) are rarely lost and could not be deleted in either E. coli or B. subtilis (Tables 2 340 and 3). Likewise, most of the frequently lost RPs (L7/L12, L9, L25, L30, L32, S21, see 341 Table S5) are incorporated into the ribosome at the late stages of its assembly (61). 342 However, some of the RPs that join the ribosome early and interact with either 16S (S6, 343 S20) or $23 S$ (L21, L24, L29, L34) rRNA can also be lost or deleted (Table 3), whereas late344 addition RPs L6, L16, L27, S2, S3, S10, S13, S14, and S19 are seldom lost (Table S5) and 345 could not be deleted in E. coli or B. subtilis. Thus, there seems to be, at best, only a weak 346 trend in the expected direction, namely, that RPs that are located on the surface of the 347 ribosome and are attached late during the ribosome assembly are frequently lost in 348 evolution and are often non-essential. A detailed accounting of specific protein-rRNA 349 and protein-protein contacts (25) could eventually provide a better predictor of the RP 350 loss propensity (non-essentiality).

Similar trends are detectable among the archaea-specific RPs. The L13e protein, 352 which is lost in all tiny archaeal genomes (Table 1) and is also missing in euryarchaea 353 and nearly all thaumarchaea (Table 2), is only partially surface-exposed: its $\mathrm{N}$-terminal 354 loop and the first $\alpha$-helix project deep into the core of the $50 \mathrm{~S}$ subunit (Fig. 2C,D). Of the 355 two 'promiscuous' surface proteins, L14e and S24e, that are present in two copies in the 356 archaeal ribosome (55) (Fig. 2C,D), the former is often lost but the latter is never missing 
357 in archaea (Table 2). Among other frequently lost archaea-specific RPs (Table 2),

358 L20a/L18a (aka LX) and L30e are surface proteins, but L34e and L35ae are mostly buried

359 and L39e is only partially surface-exposed $(54,55)$. Conversely, surface-exposed proteins

360 S3ae, S4e, S6e, S19e, and S28e (Fig. 2C,D) were never found to be missing in any of the

361 analyzed archaeal genomes (Table 2).

\section{DISCUSSION}

363 The overall conservation of the translation machinery among the bacteria, archaea, 364 and eukaryotes (Table S1) is the strongest evidence of the common origin of all 365 organisms, which allows including them in a single, universal Tree of Life $(26,27,62)$. 366 Indeed, 33 RPs are universal, that is, in all likelihood, have been conserved throughout 367 the more than 3.5 billion years of the evolution of life $(63,64)$. Therefore, it is 368 remarkable that genes for some of these universal RPs can be lost in many bacteria and 369 archaea organisms with tiny genomes (Table 1) as well as in certain bacterial and 370 archaeal lineages with larger genomes (Table 2), and can be deleted from the genomes 371 of model bacteria without substantial loss of viability (Tables 3 and S4).

372 Here, we sought to trace the loss of RP genes in a relatively small and well-defined 373 set of bacterial and archaeal genomes covered by the recent release of the COG 374 database (28). This work was prompted by the observation that relatively few of the RP 375 COGs had "perfect" phyletic patterns, that is, included representatives of all 1,309 376 organisms (or, in the case of domain-specific RPs, all representatives of either 1,187 377 bacteria or 122 archaea, respectively). Based on the previous studies $(1-5,21,25,43)$,, 378 the missing RPs were expected to come primarily from the highly degraded genomes 379 with an additional contribution of lineage-specific gene loss. These expectations proved 380 to be largely correct, with organisms with tiny genomes (Table 1) and lineage-specific 381 gene loss (Table 2) accounting for a large fraction of imperfect phyletic patterns among 382 the RPs. 
In addition, we identified multiple instances of frameshifted ORFs (Table S2) that

384 were likely generated by sequencing errors. In certain cases, these frameshifts occurred 385 in long stretches of identical nucleotides, which raises the possibility that some of them 386 could represent authentic programmed frameshifts (40). This possibility, however, 387 seems unlikely in cases where the genome of a closely related bacterium encodes an 388 intact full-length ORF. Imperfect phyletic patterns can also be caused by problems in 389 genome annotation whereby certain ORFs, particularly short ones, are overlooked by 390 the annotation software (Table S3). Given the widespread loss of RP genes (Tables 1 and 3912 2), it would not be realistic to require every newly sequenced genome to contain the full 392 set of RP genes. Nevertheless, when a bacterial or archaeal genome of more than $1 \mathrm{Mb}$ 393 in size lacks any of the 43 widely conserved RPs (Table 2), it should raise a red flag. 394 Further, the example of "Ca. Nanopusillus acidilobi" (Table 1) shows that short and/or 395 divergent RPs from poorly studied bacteria and archaea should not be deemed 396 pseudogenes without clear evidence that this is indeed the case. In particular, as shown 397 in Table 2, almost all archaeal genomes encode the 33 universal and 20 archaea-specific 398 RPs, so that the absence of any of these genes in an archaeal genome is highly unlikely. So, what conclusions can be drawn from the patterns of RP loss - and conservation 400 - patterns shown in Tables 1, 2, and 3? First, these observations validate the previously 401 noted trend of independent loss of orthologous RP genes in several phylogenetically 402 distant lineages (4). Examples include the loss of $L 25$ in certain members of 403 Actinobacteria, Firmicutes, and Mollicutes, loss of L30 in some members of Clostridia 404 and Alphaproteobacteria, loss of L34 in certain Clostridia and Planctomycetes, and the 405 loss of S21 in several distinct bacterial phyla (Table 2). Among archaea-specific RPs, it is 406 worth noting the simultaneous absence of L13e, L14e, L20a, L34e, and L35ae proteins in 407 many members of Euryarchaeota and Thaumarchaeota (Table 2).

408 The second prominent trend is the gradual loss of RPs within a single lineage. Thus, 409 previous analyses of the mollicute genomes reported the absence of the genes for $L 25$, 410 L30, and S1 $(21,43)$. This pattern was confirmed here for several mollicute genomes, 
411 albeit not for the two recently sequenced unclassified members of Tenericutes. These

412 comparisons allowed us to reconstruct a possible scenario of RP gene loss in the phylum

413 Tenericutes (Figure 3). It appears that progressive genome reduction during the 414 evolution of the Mollicutes first led to the loss of L25, then S1, followed by either L30 or 415 L35, and culminated in the loss of two more genes in "Ca. Hepatoplasma 416 crinochetorum" (Fig. 3). Remarkably, the same set of genes coding for L25, L30, and S1 417 that is missing in Mycoplasma spp. is also missing in the genome of Erysipelothrix 418 rhusiopathiae, a member of the Firmicutes branch that is closest to the Mollicutes (65).

419 The loss of RPs in phylum- or class-level lineages generally correlates with two 420 other hallmarks of non-essentiality, the availability of deletion mutants in model 421 organisms and frequency of loss in tiny genomes (Table 3). The genes that encode 422 apparently non-essential RPs, but for which few or no losses were observed in the 423 genomes included in the COGs, are likely to be lost in other bacterial or archaeal 424 genomes, especially, small ones. For example, the loss of L1 and/or L9, which was 425 detected in several tiny genomes from "Other bacteria" (Table 1), has been reported to 426 be widespread among the Candidate Phyla Radiation (Patescibacteria), a vast and 427 diversified group of poorly characterized bacteria that are thought to be symbionts or 428 parasites of other bacteria (66).

An interesting aspect of the non-essential RP gene set is its potential use in 430 synthetic biology. In previous attempts to construct a "minimal" bacterial cell, either 431 fully synthetic $(23,67-69)$ or highly streamlined (70), the researchers aimed at obtaining 432 rapidly growing microorganisms and chose not to tweak their RP gene content. 433 Accordingly, the synthetic Mycoplasma genitalium JCVI-1.0 (GenBank accession number 434 CP000925) and both synthetic versions of Mycoplasma mycoides, JCVI-syn1.0 (GenBank: 435 CP002027) and JCVI-syn3.0 (GenBank: CP016816), included all 50 RP genes that are 436 normally found in these organisms (which do not encode L25, L30, and S1). The 437 synthetic genome of Caulobacter ethensis-2.0 included all core RPs of Caulobacter 438 crescentus except for L1 and L6 (69). The MiniBacillus project ended up including all 54 
439 core RP genes (Table S1), as well as YIXQ (L7ae) and paralogs of L6, L33, and S14 (70, 71).

440 Future attempts at constructing streamlined bacterial genomes might involve attempts

441 to substantially reduce the sets of RP genes. In contrast, in archaea, the overall 442 conservation of the RPs leaves few choices for such gene deletion.

443 It should be noted that the absence of RP genes was discussed here - and elsewhere 444 - in terms of genome compaction and lineage-specific gene loss, based on the presence 445 of the respective RP genes in the genomes of closely related organisms. However, a 446 recent study (72) has shown that certain RPs are encoded by phages, which indicated 447 the distinct possibility of the acquisition of the RP genes through lateral transfer. The 448 L7/L12 and S21 genes were most widespread in phages, and some phages also encoded 449 L9 and S30. Further, analysis of viral metagenomes revealed the occasional presence of 450 genes for L11, L19, L31, L33, S6, S9, S15, and S20 and, in some instances, for L2 and L10 451 (72). The presence of such genes in phage genomes could be explained by the pressure 452 on the phage to provide the cell with its own RPs to accelerate translation, particularly 453 when the respective genes are missing in the host genome. Indeed, the RPs listed above 454 are often lost, both in organisms with tiny genomes and in specific bacterial lineages 455 (Tables 1 and 2).

456 Overall, the observations presented here show that the evolution of RPs is more 457 malleable and dynamic than previously thought. It remains to be seen whether 458 additional massive sequencing of diverse bacterial and archaeal genomes leads to 459 further erosion of the set of universal RPs and/or of those that are conserved within the 460 archeal or bacterial domains of life.

MATERIALS AND METHODS

462 Genome coverage and protein selection

463 The list of bacterial and archaeal genomes used in this work was taken from the 464 recent release of the COG database (28). This set includes 1,309 complete genomes of 4651,187 bacteria and 122 archaea, most of them with a single representative of the 
466 respective genus $(1,234$ named genera, see

467 https://ftp.ncbi.nih.gov/pub/COG/COG2020/data/cog-20.org.csv for the full list).

468 The list of RPs analyzed in this work was also taken from the COG database (the 469 'Ribosome 30 S subunit', 'Ribosome 50 S subunit', and 'Archaeal ribosomal proteins' 470 groups in the 'COG Pathways' list, https://www.ncbi.nlm.nih.gov/research/cog/ 471 pathways). This list included 54 bacterial (or universal) proteins and 33 archaea-specific 472 proteins, as listed in the Supplementary Table S1. Two auxiliary RPs, S22 (RpsV, Sra) and 473 S31e (Thx), were not included in this survey because there were no respective COGs in 474 the database. S22 protein is mostly expressed during the stationary phase and appears 475 to be non-essential for the viability of E. coli (38). S31e (Thx) is part of the 30S subunit in 476 Thermus thermophilus (53) and is mostly found in Bacteroidetes, Proteobacteria, and 477 several other phyla. The RNA-binding protein L7ae (YlXQ) is associated with archaeal 478 ribosomes but apparently not with bacterial ribosomes (73). The S1 protein was deemed 479 present when the respective ORF included three or more S1-like domains. The archaeal 480 protein set did not include L38e and L41e proteins (arCOG04057 and arCOG06624 in 481 (74), respectively), which are not represented in the current set of COGs.

\section{Identification of missing ribosomal genes}

The list of RPs missing from each genome was taken from the phyletic profiles of 484 the respective COGs. The nucleotide sequences of the respective genomes were 485 searched with representative RP sequences (taken either from Table S1 or from closely 486 related taxa) using the recent version of the TBLASTn program (41) that allows the 487 selection of specific organisms based on the NCBI Taxonomy assignments. The resulting 488 BLAST hits (cut-off E-value, 0.1) were verified using the CDD-search (75) and compared 489 against the protein sets in GenBank and RefSeq databases. The confirmed RP ORFs that 490 were missing in GenBank were classified as either frameshifted (or, in several cases, 491 those missing a recognizable start codon) or overlooked; for the latter ones, the full-size 492 ORFs were translated from the genomic sequences using ORFfinder 
493 (https://www.ncbi.nlm.nih.gov/orffinder/). Representative frameshifted and overlooked

494 ORFs are listed, respectively, in Table S2 and Table S3.

495 The RPs that produced no statistically significant hits in TBLASTn searches were 496 classified as missing in the respective genomes. These genomes were classified into tiny 497 (less than $1 \mathrm{Mb}$ in size for bacteria or $1.2 \mathrm{Mb}$ for archaea) and regular-sized; they were 498 further sorted by phyla according to their COG assignments (which rely on the NCBI 499 Taxonomy database).

\section{Identification of non-essential ribosomal genes}

501 The lists of non-essential ribosomal genes (Table S4) were collected from the 502 literature and two online databases, Database of Essential Genes [DEG, (13)] and the 503 Online Gene Essentiality database [OGEE, (14)]. Since these databases, and most of the 504 original literature, focused on essential genes, the supplementary material files for each 505 paper were individually checked to select those genes that had been positively 506 identified as non-essential and ignore those genes that were not listed as essential but 507 whose status had not been specified.

508 To assess the ribosomal localization of selected RPs, the structures of ribosomes of 509 E. coli (PDB: 7K00) (56) and Pyrococcus furiosus (PDB: 4V6U) (55) were downloaded 510 from the Protein Data Bank and visualized using PyMOL v. 1.0 (Schrödinger, LLC). 511 Individual surface proteins were colored based on their loss propensity (Table 2).

\section{ACKNOWLEDGEMENTS}

514 This study was supported by the Intramural Research Program of the U.S. National 515 Library of Medicine at the National Institutes of Health. 


\section{REFERENCES}

518 1. Lecompte O, Ripp R, Thierry JC, Moras D, Poch O. 2002. Comparative analysis of 519 ribosomal proteins in complete genomes: an example of reductive evolution at the domain scale. Nucleic Acids Res 30:5382-5390.

522

2. Mushegian A. 2005. Protein content of minimal and ancestral ribosome. RNA

523 11:1400-1406.

524

3. Kaczanowska M, Ryden-Aulin M. 2007. Ribosome biogenesis and the translation process in Escherichia coli. Microbiol Mol Biol Rev 71:477-494.

526

4. Yutin N, Puigbo P, Koonin EV, Wolf YI. 2012. Phylogenomics of prokaryotic ribosomal proteins. PLoS One 7:e36972.

528

5. Ban N, Beckmann R, Cate JH, Dinman JD, Dragon F, Ellis SR, Lafontaine DL, Lindahl L, Liljas A, Lipton JM, McAlear MA, Moore PB, Noller HF, Ortega J, Panse VG, Ramakrishnan V, Spahn CM, Steitz TA, Tchorzewski M, Tollervey D, Warren AJ, Williamson JR, Wilson D, Yonath A, Yusupov M. 2014. A new system for naming ribosomal proteins. Curr Opin Struct Biol 24:165-169.

6. Baba T, Ara T, Hasegawa M, Takai Y, Okumura Y, Baba M, Datsenko KA, Tomita M, Wanner BL, Mori H. 2006. Construction of Escherichia coli K-12 in-frame, single-gene knockout mutants: the Keio collection. Mol Syst Biol 2:2006.0008.

7. Akanuma G, Nanamiya H, Natori Y, Yano K, Suzuki S, Omata S, Ishizuka M, Sekine Y, Kawamura F. 2012. Inactivation of ribosomal protein genes in Bacillus subtilis reveals importance of each ribosomal protein for cell proliferation and cell differentiation. J Bacteriol 194:6282-6291.

8. Ueta M, Wada C, Wada A. 2020. YkgM and YkgO maintain translation by

9. Nanamiya H, Akanuma G, Natori Y, Murayama R, Kosono S, Kudo T, Kobayashi replacing their paralogs, zinc-binding ribosomal proteins $\mathrm{L} 31$ and $\mathrm{L} 36$, with identical activities. Genes Cells 25:562-581.

11. Akanuma G, Kobayashi A, Suzuki S, Kawamura F, Shiwa Y, Watanabe S, controlling alternation of two types of L31 protein in the Bacillus subtilis ribosome. Mol Microbiol 52:273-283.

10. Natori Y, Nanamiya H, Akanuma G, Kosono S, Kudo T, Ochi K, Kawamura F. 2007. A fail-safe system for the ribosome under zinc-limiting conditions in Bacillus subtilis. Mol Microbiol 63:294-307. Yoshikawa H, Hanai R, Ishizuka M. 2014. Defect in the formation of 705 ribosomes caused by lack of ribosomal protein $\mathrm{L} 34$ can be suppressed by magnesium. J Bacteriol 196:3820-3830. 
557 13. Luo H, Lin Y, Liu T, Lai FL, Zhang CT, Gao F, Zhang R. 2021. DEG 15, an update of

558

559

560

561

562

563

564

565

566

567

568

569

570

571

572

573

574

575

576

577

578

579

580

581

582

583

584

585

586

587

588

589

590

591

592

593

594

595

596

597

598 the Database of Essential Genes that includes built-in analysis tools. Nucleic Acids Res 49:D677-D686.

14. Gurumayum S, Jiang P, Hao X, Campos TL, Young ND, Korhonen PK, Gasser RB, Bork P, Zhao XM, He L, Chen WH. 2021. OGEE v3: Online GEne Essentiality database with increased coverage of organisms and human cell lines. Nucleic Acids Res 49:D998-D1003.

15. Ji Y, Zhang B, Van SF, Horn, Warren P, Woodnutt G, Burnham MK, Rosenberg M. 2001. Identification of critical staphylococcal genes using conditional phenotypes generated by antisense RNA. Science 293:2266-2269.

16. Forsyth RA, Haselbeck RJ, Ohlsen KL, Yamamoto RT, Xu H, Trawick JD, Wall D, Wang L, Brown-Driver V, Froelich JM, C KG, King P, McCarthy M, Malone C, Misiner B, Robbins D, Tan Z, Zhu Zy ZY, Carr G, Mosca DA, Zamudio C, Foulkes JG, Zyskind JW. 2002. A genome-wide strategy for the identification of essential genes in Staphylococcus aureus. Mol Microbiol 43:1387-1400.

17. Yin D, Ji Y. 2002. Genomic analysis using conditional phenotypes generated by antisense RNA. Curr Opin Microbiol 5:330-333.

18. Glass JI, Assad-Garcia N, Alperovich N, Yooseph S, Lewis MR, Maruf M, Hutchison CA, 3rd, Smith HO, Venter JC. 2006. Essential genes of a minimal bacterium. Proc Natl Acad Sci USA 103:425-430.

19. French CT, Lao P, Loraine AE, Matthews BT, Yu H, Dybvig K. 2008. Large-scale transposon mutagenesis of Mycoplasma pulmonis. Mol Microbiol 69:67-76.

20. Dybvig K, Lao P, Jordan DS, Simmons WL. 2010. Fewer essential genes in mycoplasmas than previous studies suggest. FEMS Microbiol Lett 311:51-55.

21. McCutcheon JP, Moran NA. 2011. Extreme genome reduction in symbiotic bacteria. Nat Rev Microbiol 10:13-26.

22. Lluch-Senar M, Delgado J, Chen WH, Llorens-Rico V, O'Reilly FJ, Wodke JA, Unal EB, Yus E, Martinez S, Nichols RJ, Ferrar T, Vivancos A, Schmeisky A, Stülke J, van Noort V, Gavin AC, Bork P, Serrano L. 2015. Defining a minimal cell: essentiality of small ORFs and ncRNAs in a genome-reduced bacterium. Mol Syst Biol 11:780.

23. Glass JI, Merryman C, Wise KS, Hutchison CA, 3rd, Smith HO. 2017. Minimal cells - real and imagined. Cold Spring Harb Perspect Biol 9:a023861.

24. Breuer M, Earnest TM, Merryman C, Wise KS, Sun L, Lynott MR, Hutchison CA, Smith HO, Lapek JD, Gonzalez DJ, de Crecy-Lagard V, Haas D, Hanson AD, Labhsetwar P, Glass JI, Luthey-Schulten Z. 2019. Essential metabolism for a minimal cell. eLife 8:e36842.

25. Nikolaeva DD, Gelfand MS, Garushyants SK. 2021. Simplification of ribosomes in bacteria with tiny genomes. Mol Biol Evol 38:58-66.

26. Ciccarelli FD, Doerks T, von Mering C, Creevey CJ, Snel B, Bork P. 2006. Toward automatic reconstruction of a highly resolved tree of life. Science 311:12831287. 
599

600

601

602

603

604

605

606

607

608

609

610

611

612

613

614

615

616

617

618

619

620

621

622

623

624

625

626

627

628

629

630

631

632

633

634

635

636

637

638

27. Fournier GP, Gogarten JP. 2010. Rooting the ribosomal tree of life. Mol Biol Evol 27:1792-1801.

28. Galperin MY, Wolf YI, Makarova KS, Vera Alvarez R, Landsman D, Koonin EV. 2021. COG database update: Focus on microbial diversity, model organisms, and widespread pathogens. Nucleic Acids Res 49:D274-D281.

29. Tatusov RL, Galperin MY, Natale DA, Koonin EV. 2000. The COG database: a tool for genome-scale analysis of protein functions and evolution. Nucleic Acids Res 28:33-36.

30. Tatusov RL, Koonin EV, Lipman DJ. 1997. A genomic perspective on protein families. Science 278:631-637.

31. Galperin MY, Makarova KS, Wolf YI, Koonin EV. 2015. Expanded microbial genome coverage and improved protein family annotation in the COG database. Nucleic Acids Res 43:D261-D269.

32. Tatusov RL, Natale DA, Garkavtsev IV, Tatusova TA, Shankavaram UT, Rao BS, Kiryutin B, Galperin MY, Fedorova ND, Koonin EV. 2001. The COG database: new developments in phylogenetic classification of proteins from complete genomes. Nucleic Acids Res 29:22-28.

33. Kristensen DM, Kannan L, Coleman MK, Wolf YI, Sorokin A, Koonin EV, Mushegian A. 2010. A low-polynomial algorithm for assembling clusters of orthologous groups from intergenomic symmetric best matches. Bioinformatics 26:1481-1487.

34. Natale DA, Galperin MY, Tatusov RL, Koonin EV. 2000. Using the COG database to improve gene recognition in complete genomes. Genetica 108:9-17.

35. Galperin MY, Kristensen DM, Makarova KS, Wolf YI, Koonin EV. 2019. Microbial genome analysis: the COG approach. Brief Bioinform 20:1063-1070.

36. Koonin EV, Galperin MY. 2003. Sequence - Evolution - Function: Computational Approaches in Comparative Genomics, 2010/12/07 ed. Kluwer Academic, Boston.

37. Choli T, Franceschi F, Yonath A, Wittmann-Liebold B. 1993. Isolation and characterization of a new ribosomal protein from the thermophilic eubacteria, Thermus thermophilus, T. aquaticus and T. flavus. Biol Chem Hoppe Seyler 374:377-383.

38. Izutsu K, Wada C, Komine Y, Sako T, Ueguchi C, Nakura S, Wada A. 2001. Escherichia coli ribosome-associated protein SRA, whose copy number increases during stationary phase. J Bacteriol 183:2765-2773.

39. Klimke W, O'Donovan C, White O, Brister JR, Clark K, Fedorov B, Mizrachi I, Pruitt KD, Tatusova T. 2011. Solving the problem: Genome annotation standards before the data deluge. Stand Genomic Sci 5:168-193.

40. Farabaugh PJ. 1996. Programmed translational frameshifting. Annu Rev Genet 30:507-528. 
41. Altschul SF, Madden TL, Schaffer AA, Zhang J, Zhang Z, Miller W, Lipman DJ. 1997. Gapped BLAST and PSI-BLAST: a new generation of protein database search programs. Nucleic Acids Res 25:3389-3402.

42. Wurch L, Giannone RJ, Belisle BS, Swift C, Utturkar S, Hettich RL, Reysenbach AL, Podar M. 2016. Genomics-informed isolation and characterization of a symbiotic Nanoarchaeota system from a terrestrial geothermal environment. Nat Commun 7:12115.

43. Grosjean H, Breton M, Sirand-Pugnet P, Tardy F, Thiaucourt F, Citti C, Barre A, Yoshizawa S, Fourmy D, de Crecy-Lagard V, Blanchard A. 2014. Predicting the minimal translation apparatus: lessons from the reductive evolution of mollicutes. PLoS Genet 10:e1004363.

44. Miller IJ, Weyna TR, Fong SS, Lim-Fong GE, Kwan JC. 2016. Single sample resolution of rare microbial dark matter in a marine invertebrate metagenome. Sci Rep 6:34362.

45. McCutcheon JP, von Dohlen CD. 2011. An interdependent metabolic patchwork in the nested symbiosis of mealybugs. Curr Biol 21:1366-1372.

46. Hutchison CA, Peterson SN, Gill SR, Cline RT, White O, Fraser CM, Smith HO, Venter JC. 1999. Global transposon mutagenesis and a minimal Mycoplasma genome. Science 286:2165-2169.

47. Goodman AL, McNulty NP, Zhao Y, Leip D, Mitra RD, Lozupone CA, Knight R, Gordon JI. 2009. Identifying genetic determinants needed to establish a human gut symbiont in its habitat. Cell Host Microbe 6:279-289.

48. Veeranagouda Y, Husain F, Tenorio EL, Wexler HM. 2014. Identification of genes required for the survival of $B$. fragilis using massive parallel sequencing of a saturated transposon mutant library. BMC Genomics 15:429.

49. Commichau FM, Pietack N, Stülke J. 2013. Essential genes in Bacillus subtilis: a re-evaluation after ten years. Mol Biosyst 9:1068-1075.

50. Shoji S, Dambacher CM, Shajani Z, Williamson JR, Schultz PG. 2011. Systematic chromosomal deletion of bacterial ribosomal protein genes. J Mol Biol 413:751761.

51. Cate JH, Yusupov MM, Yusupova GZ, Earnest TN, Noller HF. 1999. X-ray crystal structures of 70S ribosome functional complexes. Science 285:2095-2104.

52. Ban N, Nissen P, Hansen J, Moore PB, Steitz TA. 2000. The complete atomic structure of the large ribosomal subunit at $2.4 \AA$ resolution. Science $\mathbf{2 8 9}: 905-$ 920.

53. Wimberly BT, Brodersen DE, Clemons WM, Jr., Morgan-Warren RJ, Carter AP, Vonrhein C, Hartsch T, Ramakrishnan V. 2000. Structure of the 305 ribosomal subunit. Nature 407:327-339.

54. Greber BJ, Boehringer D, Godinic-Mikulcic V, Crnkovic A, Ibba M, WeygandDurasevic I, Ban N. 2012. Cryo-EM structure of the archaeal 50 S ribosomal subunit in complex with initiation factor 6 and implications for ribosome evolution. J Mol Biol 418:145-160. 
681 55. Armache JP, Anger AM, Marquez V, Franckenberg S, Frohlich T, Villa E,

682

683

684

685

686

687

688

689

690

691

692

693

694

695

696

697

698

699

700

701

702

703

704

705

706

707

708

709

710

711

712

713

714

715

716

717

718

719

720

721

722 Berninghausen O, Thomm M, Arnold GJ, Beckmann R, Wilson DN. 2013. Promiscuous behaviour of archaeal ribosomal proteins: implications for eukaryotic ribosome evolution. Nucleic Acids Res 41:1284-1293.

56. Watson ZL, Ward FR, Meheust R, Ad O, Schepartz A, Banfield JF, Cate JH. 2020. Structure of the bacterial ribosome at $2 \AA$ resolution. eLife 9:e60482.

57. Held WA, Ballou B, Mizushima S, Nomura M. 1974. Assembly mapping of $30 \mathrm{~S}$ ribosomal proteins from Escherichia coli. Further studies. J Biol Chem 249:31033111.

58. Herold M, Nierhaus KH. 1987. Incorporation of six additional proteins to complete the assembly map of the $50 \mathrm{~S}$ subunit from Escherichia coli ribosomes. J Biol Chem 262:8826-8833.

59. Nierhaus KH. 1991. The assembly of prokaryotic ribosomes. Biochimie 73:739755.

60. Shajani Z, Sykes MT, Williamson JR. 2011. Assembly of bacterial ribosomes. Annu Rev Biochem 80:501-526.

61. Chen SS, Williamson JR. 2013. Characterization of the ribosome biogenesis landscape in E. coli using quantitative mass spectrometry. J Mol Biol 425:767779.

62. Parks DH, Chuvochina M, Waite DW, Rinke C, Skarshewski A, Chaumeil PA, Hugenholtz P. 2018. A standardized bacterial taxonomy based on genome phylogeny substantially revises the tree of life. Nat Biotechnol 36:996-1004.

63. Hsiao C, Mohan S, Kalahar BK, Williams LD. 2009. Peeling the onion: ribosomes are ancient molecular fossils. Mol Biol Evol 26:2415-2425.

64. Petrov AS, Gulen B, Norris AM, Kovacs NA, Bernier CR, Lanier KA, Fox GE, Harvey SC, Wartell RM, Hud NV, Williams LD. 2015. History of the ribosome and the origin of translation. Proc Natl Acad Sci USA 112:15396-15401.

65. Yutin N, Galperin MY. 2013. A genomic update on clostridial phylogeny: Gramnegative spore formers and other misplaced clostridia. Environ Microbiol 15:2631-2641.

66. Brown CT, Hug LA, Thomas BC, Sharon I, Castelle CJ, Singh A, Wilkins MJ, Wrighton KC, Williams KH, Banfield JF. 2015. Unusual biology across a group comprising more than 15\% of domain Bacteria. Nature 523:208-211.

67. Gibson DG, Glass JI, Lartigue C, Noskov VN, Chuang RY, Algire MA, Benders GA, Montague MG, Ma L, Moodie MM, Merryman C, Vashee S, Krishnakumar R, Assad-Garcia N, Andrews-Pfannkoch C, Denisova EA, Young L, Qi ZQ, SegallShapiro TH, Calvey CH, Parmar PP, Hutchison CA, 3rd, Smith HO, Venter JC. 2010. Creation of a bacterial cell controlled by a chemically synthesized genome. Science 329:52-56.

68. Hutchison CA, 3rd, Chuang RY, Noskov VN, Assad-Garcia N, Deerinck TJ, Ellisman MH, Gill J, Kannan K, Karas BJ, Ma L, Pelletier JF, Qi ZQ, Richter RA, Strychalski EA, Sun L, Suzuki Y, Tsvetanova B, Wise KS, Smith HO, Glass JI, 
Merryman C, Gibson DG, Venter JC. 2016. Design and synthesis of a minimal bacterial genome. Science 351:aad6253.

69. Venetz JE, Del Medico L, Wolfle A, Schachle P, Bucher Y, Appert D, Tschan F, Flores-Tinoco CE, van Kooten M, Guennoun R, Deutsch S, Christen M, Christen B. 2019. Chemical synthesis rewriting of a bacterial genome to achieve design flexibility and biological functionality. Proc Natl Acad Sci USA 116:8070-8079.

70. Reuss DR, Commichau FM, Gundlach J, Zhu B, Stülke J. 2016. The blueprint of a minimal cell: MiniBacillus. Microbiol Mol Biol Rev 80:955-987.

71. Reuss DR, Altenbuchner J, Mader U, Rath H, Ischebeck T, Sappa PK, Thurmer A, Guerin C, Nicolas P, Steil L, Zhu B, Feussner I, Klumpp S, Daniel R, Commichau FM, Volker U, Stülke J. 2017. Large-scale reduction of the Bacillus subtilis genome: consequences for the transcriptional network, resource allocation, and metabolism. Genome Res 27:289-299.

72. Mizuno CM, Guyomar C, Roux S, Lavigne R, Rodriguez-Valera F, Sullivan MB, Gillet R, Forterre P, Krupovic M. 2019. Numerous cultivated and uncultivated viruses encode ribosomal proteins. Nat Commun 10:752.

73. Baird NJ, Zhang J, Hamma T, Ferre-D'Amare AR. 2012. YbxF and YlxQ are bacterial homologs of L7Ae and bind K-turns but not K-loops. RNA 18:759-770.

74. Makarova KS, Wolf YI, Koonin EV. 2015. Archaeal Clusters of Orthologous Genes (arCOGs): An update and application for analysis of shared features between Thermococcales, Methanococcales, and Methanobacteriales. Life (Basel) 5:818840.

75. Lu S, Wang J, Chitsaz F, Derbyshire MK, Geer RC, Gonzales NR, Gwadz M, Hurwitz DI, Marchler GH, Song JS, Thanki N, Yamashita RA, Yang M, Zhang D, Zheng C, Lanczycki CJ, Marchler-Bauer A. 2020. CDD/SPARCLE: the conserved domain database in 2020. Nucleic Acids Res 48:D265-D268.

76. Gupta RS, Sawnani S, Adeolu M, Alnajar S, Oren A. 2018. Phylogenetic framework for the phylum Tenericutes based on genome sequence data: proposal for the creation of a new order Mycoplasmoidales ord. nov., containing two new families Mycoplasmoidaceae fam. nov. and Metamycoplasmataceae fam. nov. harbouring Eperythrozoon, Ureaplasma and five novel genera. Antonie Van Leeuwenhoek 111:1583-1630. 


\section{Table 1. Ribosomal genes missing in organisms with tiny genomes}

\begin{tabular}{|c|c|c|c|c|}
\hline Organism name $e^{a, b}$ & \begin{tabular}{|l|} 
Genome \\
size, $\mathbf{k b}$ \\
\end{tabular} & $\begin{array}{l}\text { Taxo- } \\
\text { nomy }\end{array}$ & Missing proteins (No.) ${ }^{c}$ & Found by TBLASTn \\
\hline \multicolumn{5}{|l|}{ BACTERIA } \\
\hline $\begin{array}{l}\text { "Ca. Nasuia deltocephalini- } \\
\text { cola NAS-ALF" }\end{array}$ & 112.1 & Beta & $\begin{array}{l}\text { L1, L9, L10, L13, L18, L19, L21, L22, } \\
\text { L24, L28, L29, L30, L31, L32, L33, } \\
\text { L35, S16, S18, S20, S21 (20) }\end{array}$ & \\
\hline $\begin{array}{l}\text { "Ca. Vidania fulgoroideae } \\
\text { OLIH" }\end{array}$ & 136.1 & Beta & $\begin{array}{l}\text { L9, L10, L17, L19, L21, L22, L23, } \\
\text { L24, L28, L29, L30, L31, L32, L35, } \\
\text { S2, S6, S15, S16, S17, S20, S21 (21) }\end{array}$ & \\
\hline $\begin{array}{l}\text { "Ca. Hodgkinia cicadicola } \\
\text { Dsem" }\end{array}$ & 143.8 & Alpha & $\begin{array}{l}\text { L1, L9, L18, L19, L21, L22, L23, L24, } \\
\text { L29, L30, L31, L32, L34, S15, S20, } \\
\text { S21 (16) }\end{array}$ & S6 \\
\hline $\begin{array}{l}\text { "Ca. Tremblaya phenacola } \\
\text { PAVE" }\end{array}$ & 171.5 & Beta & $\begin{array}{l}\text { L9, L21, L23, L24, L28, L29, L32, } \\
\text { L34 (8) }\end{array}$ & \\
\hline "Ca. Carsonella ruddii DC" & 174.0 & Gamma & $\begin{array}{l}\text { L9, L10, L13, L17, L18, L19, L21, } \\
\text { L23, L24, L25, L29, L30, L32, L34, } \\
\text { L35, S6, S15, S18, S20 (20) }\end{array}$ & \\
\hline "Ca. Sulcia muelleri PUNC" & 190.7 & $\begin{array}{l}\text { Bacteroi- } \\
\text { detes }\end{array}$ & L23, L24, L29, L30 (4) & \\
\hline $\begin{array}{l}\text { "Ca. Zinderia insecticola } \\
\text { CARI" }\end{array}$ & 208.6 & Beta & $\begin{array}{l}\text { L9, L23, L28, L29, L30, L32, L35, } \\
\text { S6, S18, S20 (10) }\end{array}$ & \\
\hline $\begin{array}{l}\text { "Ca. Uzinura diaspidicola } \\
\text { ASNER" }\end{array}$ & 263.4 & $\begin{array}{l}\text { Bacter- } \\
\text { oidetes }\end{array}$ & L29 & \\
\hline $\begin{array}{l}\text { "Ca. Walczuchella } \\
\text { monophlebidarum" }\end{array}$ & 309.3 & $\begin{array}{l}\text { Bactero- } \\
\text { idetes }\end{array}$ & L29 & \\
\hline "Ca. Mikella endobia" & 352.8 & Gamma & - & \\
\hline "Ca. Portiera aleyrodidarum" & 357.5 & Gamma & L30 & \\
\hline "Ca. Evansia_muelleri" & 357.5 & Gamma & L9, L30 & \\
\hline "Ca. Profftella armatura DC" & 464.9 & Beta & - & \\
\hline $\begin{array}{l}\text { "Ca. Purcelliella } \\
\text { pentastirinorum" }\end{array}$ & 479.9 & Gamma & - & \\
\hline "Ca. Moranella endobia" & 538.2 & Gamma & - & \\
\hline Mycoplasma genitalium $\mathrm{G} 37^{\mathbf{b}}$ & 580.1 & $\begin{array}{l}\text { Molli- } \\
\text { cutes }\end{array}$ & L25, L30, S1 & \\
\hline "Ca. Riesia pediculicola" & 582.1 & Gamma & L30 & \\
\hline Bacterium AB1 & 593.4 & $\mathrm{~N} / \mathrm{A}$ & $\begin{array}{l}\text { L9, L10, L19, L21, L23, L25, L29, } \\
\text { L30, L31, L32, L33, L35, S6, S15, } \\
\text { S18, S20, S21 (15) }\end{array}$ & L34 \\
\hline $\begin{array}{l}\text { Cand. division Kazan bacte- } \\
\text { rium GW2011 GWA1 } 5015\end{array}$ & 602.6 & $\begin{array}{l}\text { Other } \\
\text { bacteria }\end{array}$ & L30, S21 & L34 \\
\hline $\begin{array}{l}\text { Blattabacterium sp. (Blattella } \\
\text { germanica) Bge }\end{array}$ & 641.0 & $\begin{array}{l}\text { Bactero- } \\
\text { idetes }\end{array}$ & L30 & \\
\hline
\end{tabular}




\begin{tabular}{|c|c|c|c|c|}
\hline $\begin{array}{c}\text { Buchnera aphidicola APS } \\
\text { (Acyrthosiphon pisum) }\end{array}$ & 655.7 & Gamma & - & \\
\hline $\begin{array}{l}\text { "Ca. Hepatoplasma crino- } \\
\text { chetorum Av"b }\end{array}$ & 657.1 & $\begin{array}{l}\text { Molli- } \\
\text { cutes }\end{array}$ & L9, L25, L30, S1, S21 & \\
\hline $\begin{array}{l}\text { "Ca. Saccharibacteria oral } \\
\text { taxon TM7x" }\end{array}$ & 705.1 & $\begin{array}{l}\text { Other } \\
\text { bacteria }\end{array}$ & & \\
\hline $\begin{array}{l}\text { "Ca. Campbellbacteria bacte- } \\
\text { rium GW2011 OD1 } 34 \text { 28" }\end{array}$ & 752.6 & $\begin{array}{l}\text { Other } \\
\text { bacteria }\end{array}$ & L1, L29, L30 & L36 \\
\hline $\begin{array}{l}\text { "Ca. Blochmannia } \\
\text { pennsylvanicus BPEN" }\end{array}$ & 791.7 & Gamma & & \\
\hline $\begin{array}{l}\text { “Ca. Woesebacteria bacteri- } \\
\text { um GW2011 GWF1_31_35 }\end{array}$ & 819.5 & $\begin{array}{l}\text { Other } \\
\text { bacteria }\end{array}$ & L9, L29, L30 & \\
\hline "Ca. Fokinia solitaria" & 837.3 & Alpha & L29, L30 & \\
\hline $\begin{array}{l}\text { Cand. division TM6 bacterium } \\
\text { GW2011 GWF2_28_16 }\end{array}$ & 853.1 & $\begin{array}{l}\text { Other } \\
\text { bacteria }\end{array}$ & L9, L30, L32, S21 & L36 \\
\hline $\begin{array}{l}\text { Neorickettsia sennetsu } \\
\text { Miyayama }\end{array}$ & 859.0 & Alpha & L30 & \\
\hline $\begin{array}{l}\text { Cand. division WWE3 bacte- } \\
\text { rium RAAC2_WWE3_1 }\end{array}$ & 878.1 & $\begin{array}{l}\text { Other } \\
\text { bacteria }\end{array}$ & L9, L30, L32 & L34, L36, S14 \\
\hline $\begin{array}{l}\text { Berkelbacteria bacterium } \\
\text { GW2011 GWE1_39_12 }\end{array}$ & 915.1 & $\begin{array}{l}\text { Other } \\
\text { bacteria }\end{array}$ & L30 & L36 \\
\hline $\begin{array}{l}\text { “Ca. Xiphinematobacter } \\
\text { Idaho Grape }\end{array}$ & 915.9 & $\begin{array}{l}\text { Verruco } \\
\text { microbia }\end{array}$ & - & \\
\hline Tropheryma whipplei Twist & 927.3 & $\begin{array}{l}\text { Actino- } \\
\text { bacteria }\end{array}$ & S21 & \\
\hline $\begin{array}{l}\text { “Ca. Wolfebacteria bacterium } \\
\text { GW2011_GWB1_47_1 }\end{array}$ & 984.4 & $\begin{array}{l}\text { Other } \\
\text { bacteria }\end{array}$ & L1, L29, L30, L33, S21 & L32, L34 \\
\hline \multicolumn{5}{|l|}{ ARCHAEA $^{d}$} \\
\hline $\begin{array}{l}\text { Nanoarchaeum equitans } \\
\text { Kin4-M }\end{array}$ & 490.9 & $\begin{array}{l}\text { Other } \\
\text { archaea }\end{array}$ & L13e, L40e, S25e, S30 & L24e, L37e \\
\hline "Ca. Nanopusillus acidilobi" & 605.9 & $\begin{array}{l}\text { Other } \\
\text { archaea }\end{array}$ & L13e, L29, L39e, S27e, S30 & $\begin{array}{l}\text { L6/L9e, L16/L10ae, } \\
\text { L15e, L22, L24, } \\
\text { L35ae, L37e, S6e, } \\
\text { S15/S13e }\end{array}$ \\
\hline $\begin{array}{l}\text { "Ca. Mancarchaeum } \\
\text { acidiphilum Mia14" }\end{array}$ & 952.3 & $\begin{array}{l}\text { Other } \\
\text { archaea }\end{array}$ & $\begin{array}{l}\text { L13e, L20a/L18a, L35ae, L37e, } \\
\text { S17e, S25e, S27e, S30 }\end{array}$ & \\
\hline $\begin{array}{l}\text { Nanohaloarchaea archaeon } \\
\text { SG9 }\end{array}$ & $1,118.6$ & $\begin{array}{l}\text { Euryar- } \\
\text { chaeota }\end{array}$ & $\begin{array}{l}\text { L13e, L14e, L20a/L18a, L30e, } \\
\text { L31e, L34e, L35ae, L39e, S30 }\end{array}$ & $\begin{array}{l}\text { L18, L24e, L40e, } \\
\text { S2, S28e }\end{array}$ \\
\hline Archaeon GW2011_AR15 & 1.157 .8 & $\begin{array}{l}\text { Other } \\
\text { archaea }\end{array}$ & $\begin{array}{l}\text { L13e, L20a/L18a, L40e, S25e, } \\
\text { S26e, S30 }\end{array}$ & \\
\hline
\end{tabular}

757 a - Organism names, genome sizes, and taxonomic assignments are taken from the NCBI

758 Taxonomy database and are listed as in the COG database (28). The organisms are listed in

759 the order of their genome sizes. Ca. stands for Candidatus, Cand. - for Candidate. 
bioRxiv preprint doi: https://doi.org/10.1101/2021.01.31.429008; this version posted February 1, 2021. The copyright holder for this preprint

(which was not certified by peer review) is the author/funder. This article is a US Government work. It is not subject to copyright under 17 USC 105 and is also made available for use under a CCO license.

760 b - For genome sizes over $600 \mathrm{~kb}$, only selected organisms are shown. Only two representatives 761 of Tenericites (Mollicutes) are included. See text for discussion.

$762{ }^{c}$ - Ribosomal proteins that are missing in several distinct lineages are shown in bold.

763 - No complete archaeal genomes sequenced so far encode L9, L7/L12, L17, L19, L20, L21, L25, 764 L27, L28, L31-L36, S1, S6, S16, S18, S20, and S21, see Table S1. The proteins listed here are 765 those present in other, larger archaeal genomes.

766 


\section{Table 2. Lineage-specific loss of ribosomal proteins}

\begin{tabular}{|c|c|}
\hline Proteins (no.) & Lost in the following taxa (no. missing/no. organisms) ${ }^{a}$ \\
\hline \multicolumn{2}{|l|}{ 50S subunit } \\
\hline L2-L6, L14- L16, L20 (9) & Always present \\
\hline L7/L12, L10, L11, L27, L36 (5) & Missing only in poorly sequenced genomes \\
\hline L9, L17- L19, L22, L23 (6) & Missing only in tiny genomes (Table 1 ) \\
\hline L1, L13, L21, L24, L28 (5) & $\begin{array}{l}\text { Missing in some tiny genomes (Table } 1 \text { ) and one additional } \\
\text { (poorly sequenced?) genome }\end{array}$ \\
\hline $\mathrm{L} 25$ & $\begin{array}{l}\text { Missing in some tiny genomes (Table } 1) \text { and in Coriobacteria } \\
(11 / 11), \text { Bacillales }(6 / 50), \text { Lactobacillales (14/23), Mollicutes } \\
(12 / 14), \text { Negativicutes }(10 / 10)\end{array}$ \\
\hline L29, L31, L32, L33 & Missing in tiny genomes (Table 1) and several other genome \\
\hline L30 & $\begin{array}{l}\text { Missing in some tiny genomes (Table } 1) \text {, Halanaerobiales }(6 / 6) \text {, } \\
\text { Pelagibacterales }(2 / 2) \text {, Rickettsiales }(5 / 9)\end{array}$ \\
\hline L34 & $\begin{array}{l}\text { Missing in some tiny genomes (Table } 1), \text { Halanaerobiales }(6 / 6) \text {, } \\
\text { Planctomycetes }(12 / 14)\end{array}$ \\
\hline L35 & Missing in some tiny genomes (Table 1 ), Mollicutes (2/14) \\
\hline \multicolumn{2}{|l|}{ 30S subunit } \\
\hline S1 & Mollicutes (11/14), Dehalococcoidia (2/2), Erysipelothrix (1/1) \\
\hline S2 & Missing in two genomes: one tiny and one poorly sequenced \\
\hline S3-S5, S8, S10, S11, S13, S14 (8) & Always present \\
\hline S6, S15-S20 (7) & Missing only in tiny genomes, see Table 1 \\
\hline S7, S9, S12 (3) & Missing in a single genome, possible sequencing error \\
\hline S21 & $\begin{array}{l}\text { Actinobacteria (155/155), Deinococcus-Thermus (6/6), } \\
\text { Fusobacteria (6/6), Halanaerobiales (5/6), Thermotogae (9/9) }\end{array}$ \\
\hline \multicolumn{2}{|l|}{ Archaeal ribosomes } \\
\hline $\begin{array}{l}\text { L7ae, L12e, L15e, L18e, L19e, L24e, } \\
\text { L32e, L37ae/L43a, L44e, S3ae, S4e, } \\
\text { S6e, S8e, S19e, S24e, S28e (16) }\end{array}$ & Always present \\
\hline L21e, L31e, L37e, S17e (4) & Missing in a single genome out of 122 \\
\hline L40e, S27e & Missing in two genomes out of 122 \\
\hline $\mathrm{L} 13 \mathrm{e}$ & $\begin{array}{l}\text { Crenarchaeota (12/25), Euryarchaeota (79/79), Thaumarchaeota } \\
(11 / 12)\end{array}$ \\
\hline L14e & $\begin{array}{l}\text { Archaeoglobi (3/3), Halobacteria (31/31), Methanomicrobia } \\
\text { (18/18), Thermoplasmata (10/10), Thaumarchaeota (11/12) }\end{array}$ \\
\hline L20a/L18a & $\begin{array}{l}\text { Halobacteriales (4/11), Natrialbales (5/11), Thaumarchaeota } \\
(12 / 12)\end{array}$ \\
\hline L30e & Halobacteria (31/31), Thermoplasmata (5/10) \\
\hline L34e & $\begin{array}{l}\text { Archaeoglobi }(3 / 3) \text {, Halobacteria }(31 / 31) \text {, Methanomicrobia } \\
(18 / 18), \text { Thermoplasmata }(10 / 10) \text {, Thaumarchaeota }(12 / 12)\end{array}$ \\
\hline L35ae & $\begin{array}{l}\text { Archaeoglobi (3/3), Halobacteria (31/31), Methanomicrobia } \\
\text { (18/18), Thermoplasmata }(10 / 10) \text {, Thaumarchaeota }(12 / 12)\end{array}$ \\
\hline
\end{tabular}


bioRxiv preprint doi: https://doi.org/10.1101/2021.01.31.429008; this version posted February 1,2021 . The copyright holder for this preprint (which was not certified by peer review) is the author/funder. This article is a US Government work. It is not subject to copyright under 17 USC 105 and is also made available for use under a CCO license.

\begin{tabular}{|l|l|}
\hline S25e, S26e, S30 & Euryarchaeota $(79 / 79)$, tiny genomes \\
\hline S27ae & Haloferacales $(7 / 10)$ \\
\hline
\end{tabular}

$768{ }^{a}$ - Data from the 1,309 genomes in the COG database (28); frameshifts and point mutations in 769 RP genes (Table S3), as well as newly translated RPs (Table S4) are not counted as missing. 
bioRxiv preprint doi: https://doi.org/10.1101/2021.01.31.429008; this version posted February 1,2021 . The copyright holder for this preprint (which was not certified by peer review) is the author/funder. This article is a US Government work. It is not subject to copyright under 17 USC 105 and is also made available for use under a CCO license.

71 Table 3. Comparison of non-essentiality and gene loss of ribosomal proteins

\begin{tabular}{|c|c|c|c|c|c|c|c|c|c|c|c|c|}
\hline \multirow{2}{*}{$\begin{array}{l}\text { Protein } \\
\text { name }^{a}\end{array}$} & \multirow{2}{*}{$\begin{array}{l}\text { Gene } \\
\text { name }\end{array}$} & \multicolumn{2}{|c|}{ Deletion $^{\mathbf{b}}$} & \multicolumn{8}{|c|}{ Loss in tiny genomes $^{c}$} & \multirow[t]{2}{*}{ Lineage-specific gene loss $^{d}$} \\
\hline & & E.coli & B.sub & Nas & Vid & Hod & Tre & Car & Sul & Zin & AB1 & \\
\hline $\mathrm{uL1}$ & RplA & $\mathrm{Y}$ & $\mathrm{Y}$ & $\mathrm{Y}$ & - & $\mathrm{Y}$ & - & - & - & - & - & \\
\hline bL9 & Rpll & $\mathrm{Y}$ & $\mathrm{Y}$ & $\mathrm{Y}$ & $\mathrm{Y}$ & $\mathrm{Y}$ & $\mathrm{Y}$ & $\mathrm{Y}$ & - & $\mathrm{Y}$ & $\mathrm{Y}$ & \\
\hline uL10 & RplJ & - & - & $\mathrm{Y}$ & $\mathrm{Y}$ & - & - & $\mathrm{Y}$ & - & - & $\mathrm{Y}$ & \\
\hline uL11 & RplK & $\mathrm{Y}$ & $\mathrm{Y}$ & - & - & - & - & - & - & - & - & \\
\hline bL17 & RplQ & - & - & - & $\mathrm{Y}$ & - & - & $Y$ & - & - & - & \\
\hline uL18 & RplR & - & - & $Y$ & - & $Y$ & - & $Y$ & - & - & - & \\
\hline bL19 & RplS & - & - & $Y$ & $Y$ & $Y$ & - & $Y$ & - & - & $Y$ & \\
\hline bL21 & RplU & - & - & $\mathrm{Y}$ & $Y$ & $Y$ & $\mathrm{Y}$ & $Y$ & - & - & $\mathrm{Y}$ & \\
\hline $\mathrm{uL} 22$ & RplV & - & $Y$ & $Y$ & $Y$ & $Y$ & - & - & - & - & - & \\
\hline uL23 & RplW & - & $Y$ & - & $Y$ & $Y$ & $Y$ & $Y$ & $Y$ & $Y$ & $\mathrm{Y}$ & \\
\hline uL24 & RplX & - & - & $\mathrm{Y}$ & $Y$ & $Y$ & $Y$ & $Y$ & $Y$ & - & - & \\
\hline bL25 & RplY & $Y$ & $Y$ & - & - & - & - & $Y$ & - & - & - & Actinobacteria, Firmicutes \\
\hline bL28 & RpmB & - & $\mathrm{Y}$ & $\mathrm{Y}$ & $\mathrm{Y}$ & - & $\mathrm{Y}$ & - & - & $\mathrm{Y}$ & - & \\
\hline uL29 & $\mathrm{RpmC}$ & - & $\mathrm{Y}$ & $\mathrm{Y}$ & $\mathrm{Y}$ & $\mathrm{Y}$ & $\mathrm{Y}$ & $\mathrm{Y}$ & $\mathrm{Y}$ & $\mathrm{Y}$ & $\mathrm{Y}$ & \\
\hline uL30 & RpmD & - & - & $\mathrm{Y}$ & $\mathrm{Y}$ & $\mathrm{Y}$ & - & $Y$ & $\mathrm{Y}$ & $\mathrm{Y}$ & $\mathrm{Y}$ & Clostridia, Proteobacteria \\
\hline bL31 & RpmE & $\mathrm{Y}$ & $\mathrm{Y}$ & $\mathrm{Y}$ & $\mathrm{Y}$ & $\mathrm{Y}$ & - & - & - & - & $\mathrm{Y}$ & Tenericutes \\
\hline bL32 & RpmF & $\mathrm{Y}$ & $\mathrm{Y}$ & $\mathrm{Y}$ & $\mathrm{Y}$ & $\mathrm{Y}$ & $\mathrm{Y}$ & $\mathrm{Y}$ & - & $\mathrm{Y}$ & $\mathrm{Y}$ & \\
\hline bL33 & RpmG & $\mathrm{Y}$ & $\mathrm{Y}$ & $\mathrm{Y}$ & - & - & - & - & - & - & $\mathrm{Y}$ & \\
\hline bL34 & $\mathrm{RpmH}$ & - & $Y$ & - & - & $\mathrm{Y}$ & $\mathrm{Y}$ & $Y$ & - & - & - & Firmicutes, Planctomycetes \\
\hline bL35 & Rpml & $\mathrm{Y}$ & $\mathrm{Y}$ & $\mathrm{Y}$ & $\mathrm{Y}$ & - & - & $\mathrm{Y}$ & - & $\mathrm{Y}$ & $\mathrm{Y}$ & Tenericutes \\
\hline bL36 & RpmJ & $\mathrm{Y}$ & $\mathrm{Y}$ & - & - & - & - & - & - & - & - & \\
\hline bS6 & RpsF & $\mathrm{Y}$ & $\mathrm{Y}$ & - & $\mathrm{Y}$ & - & - & $\mathrm{Y}$ & - & $\mathrm{Y}$ & $\mathrm{Y}$ & \\
\hline uS15 & $\mathrm{RpsO}$ & $\mathrm{Y}$ & - & - & $\mathrm{Y}$ & $\mathrm{Y}$ & - & $\mathrm{Y}$ & - & - & $\mathrm{Y}$ & \\
\hline bS18 & RpsR & - & - & $\mathrm{Y}$ & - & - & - & $Y$ & - & $Y$ & $\mathrm{Y}$ & \\
\hline bS20 & RpsT & $Y$ & $Y$ & $Y$ & $Y$ & $Y$ & - & $Y$ & - & $Y$ & $Y$ & \\
\hline $\mathrm{bS} 21$ & RpsU & $Y$ & $Y$ & $\mathrm{Y}$ & $\mathrm{Y}$ & $Y$ & - & - & - & - & $\mathrm{Y}$ & $\begin{array}{l}\text { Actinobacteria, } \\
\text { Deinococcus-Thermus, } \\
\text { Fusobacteria, Thermotogae }\end{array}$ \\
\hline
\end{tabular}

a - Ribosomal protein names according to the universal nomenclature (5). Prefix 'u' indicates universal conservation of the protein, prefix ' $b$ ' indicates proteins that are specific for bacteria.

${ }^{b}$ - Successfully generated deletion mutants in $\operatorname{E}$. coli $(6,53)$ and $B$. subtilis $(7,52)$ are indicated as $Y$, absence of such mutants is indicated by a dash. See Table $\$ 4$ for details.

c- Organisms with tiny genomes are listed in the order of genome sizes (same as in Table 1): Nas, "Ca. Nasuia deltocephalinicola str. NAS-ALF"; Vid, "Ca. Vidania fulgoroideae OLIH"; Hod, "Ca. Hodgkinia cicadicola Dsem"; Tre, "Ca. Tremblaya phenacola PAVE"; Car, "Ca. Carsonella ruddii DC"; Sul, "Ca. Sulcia muelleri PUNC"; Zin, "Ca. Zinderia insecticola CARI"; $A B 1$, "bacterium AB1". Y indicates the loss of the respective gene, presence of the gene is shown by a dash.

$81^{d}$-Bacterial phyla containing the lineages that exhibit loss of the respective genes (from Table 2). 


\section{Figure legend}

783 Figure 1. Loss of ribosomal genes in bacteria and archaea with small genome sizes.

784 The number of ribosomal protein genes missing in various bacteria (A) and archaea (B) is shown 785 as a function of the genome size. Each symbol indicates a representative organism from those included in the COG database (a single genome per genus). In A, yellow circles indicate the genomes of members of Proteobacteria, blue circles - Bacteroidetes, orange squares Tenericutes, grey squares - Actinobacteria, empty squares - representatives of various phyla with 5-10 members in COGs (Aquificae, Chlamydiae, Chloroflexi, Cyanobacteria, Fusobacteria, Spirochaetes, Synergistetes, Thermotogae, and Verrucomicrobia); triangles indicate representatives of poorly sampled phyla (the "Other bacteria" group in COGs). In B, yellow circles indicate genomes of members of Crenarchaeota, blue circles - Euryarchaeota, grey squares - Thaumarchaeota, and red squares - representatives of poorly sampled phyla (the

Figure 2. Localization of certain frequently and rarely lost surface proteins in the ribosomes of

797 A, B. Crystal structure of the E. coli ribosome (PDB: 7K00), solved at $2 \AA$ resolution by Watson et

798 al., 2020 (56). C, D. Cryo-EM structure of the $P$. furiosus ribosome (PDB: 4V6U), solved at $6.6 \AA$

799 resolution by Armache et al., 2012 (55). The ribosomal RNAs are shown in grey. Unless

800 indicated otherwise, 50S subunit proteins are in wheat color and 30S subunit proteins are in

801 cyan. Proteins mentioned in the text are indicated by bright colors: frequently lost surface

802 proteins are in yellow, rarely lost ones are in green, other proteins described in the text are in

803 red, orange and magenta. The structures were visualized and colored using PyMOL v. 1.0

804 (Schrödinger, LLC).

805 Figure 3. A possible scenario of ribosomal protein loss in the Mollicutes (Tenericutes).

806 The organisms are those listed in the COG database. Based on the phylogeny of this group,

807 which divides Mollicutes into at least four distinct lineages, Acholeplasma/Phytoplasma,

808 Spiroplasma/Mesoplasma, Mycoplasma pneumoniae/Ureaplasma, and Mycoplasma hominis

809 (76), the loss of L30 and S1 may have occurred independently on two or more occasions. The

810 loss of of L25 may have occurred at an early stage in the evolution of this group or has occurred

811 several times. 


\section{Supplementary Tables}

813 Table S1. Core bacterial and archaeal proteins, their unified nomenclature of Ban et al. 2014, 814 Pfam domains, and the UniProt entries in Escherichia coli, Bacillus subtilis, Mycoplasma 815 pneumoniae, Aeropyrum pernix, Haloarcula marismortui and Saccharomyces cerevisiae.

816 Table S2. Frameshifted ribosomal proteins in the genomes covered by the COG database

817 Table S3. Unannotated ORFs coding for ribosomal proteins in the genomes covered by the $818 \quad$ COG database

819 Table S4. Experimental data on large-scale inactivation of ribosomal proteins

820 Table S5. Loss of ribosomal proteins that differ in their rRNA interactions and the order of 821 assembly, as described by Chen and Williamson, 2013.

822

823

824

825

826 
bioRxiv preprint doi: https://doi.org/10.1101/2021.01.31.429008; this version posted February 1, 2021. The copyright holder for this preprint (which was not certified by peer review) is the author/funder. This article is a US Government work. It is not subject to copyright under 17 USC 105 and is also made available for use under a CCO license.
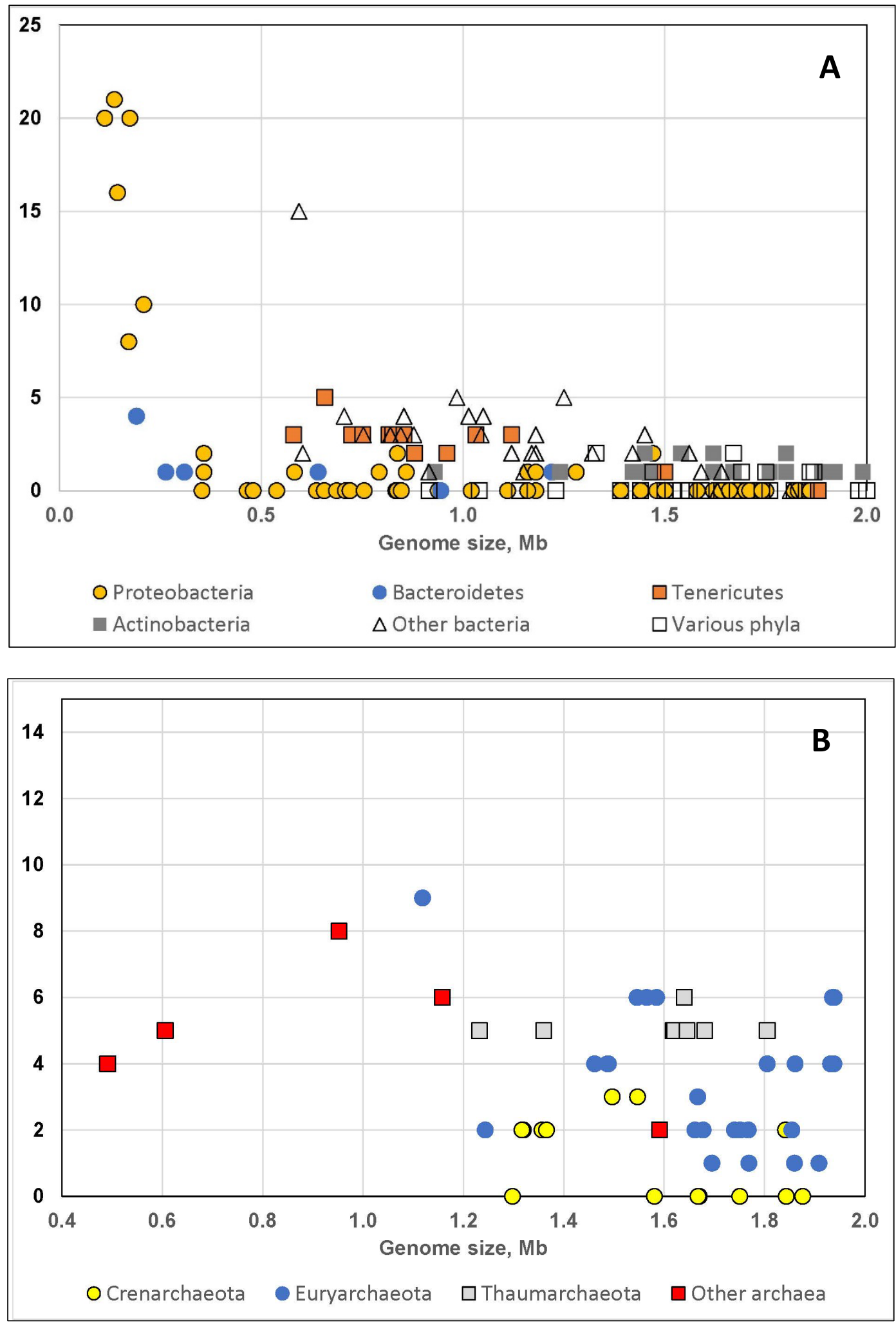

Fig. 1 
bioRxiv preprint doi: https://doi.org/10.1101/2021.01.31.429008; this version posted February 1, 2021. The copyright holder for this preprint (which was not certified by peer review) is the author/funder. This article is a US Government work. It is not subject to copyright under 17 USC 105 and is also made available for use under a CCO license.
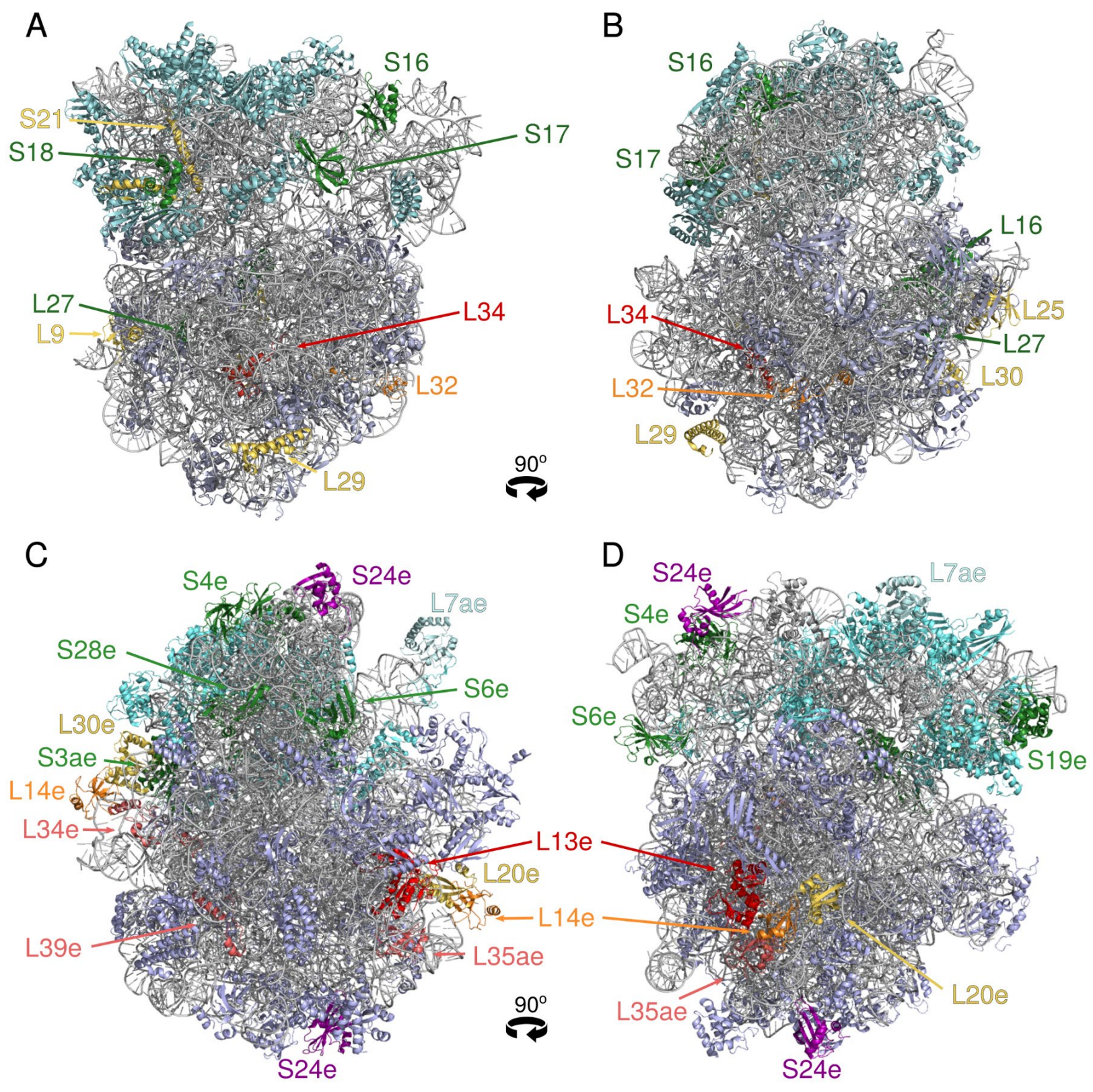

Fig. 2 
bioRxiv preprint doi: https://doi.org/10.1101/2021.01.31.429008; this version posted February 1, 2021. The copyright holder for this preprint (which was not certified by peer review) is the author/funder. This article is a US Government work. It is not subject to copyright under 17 USC 105 and is also made available for use under a CCO license.

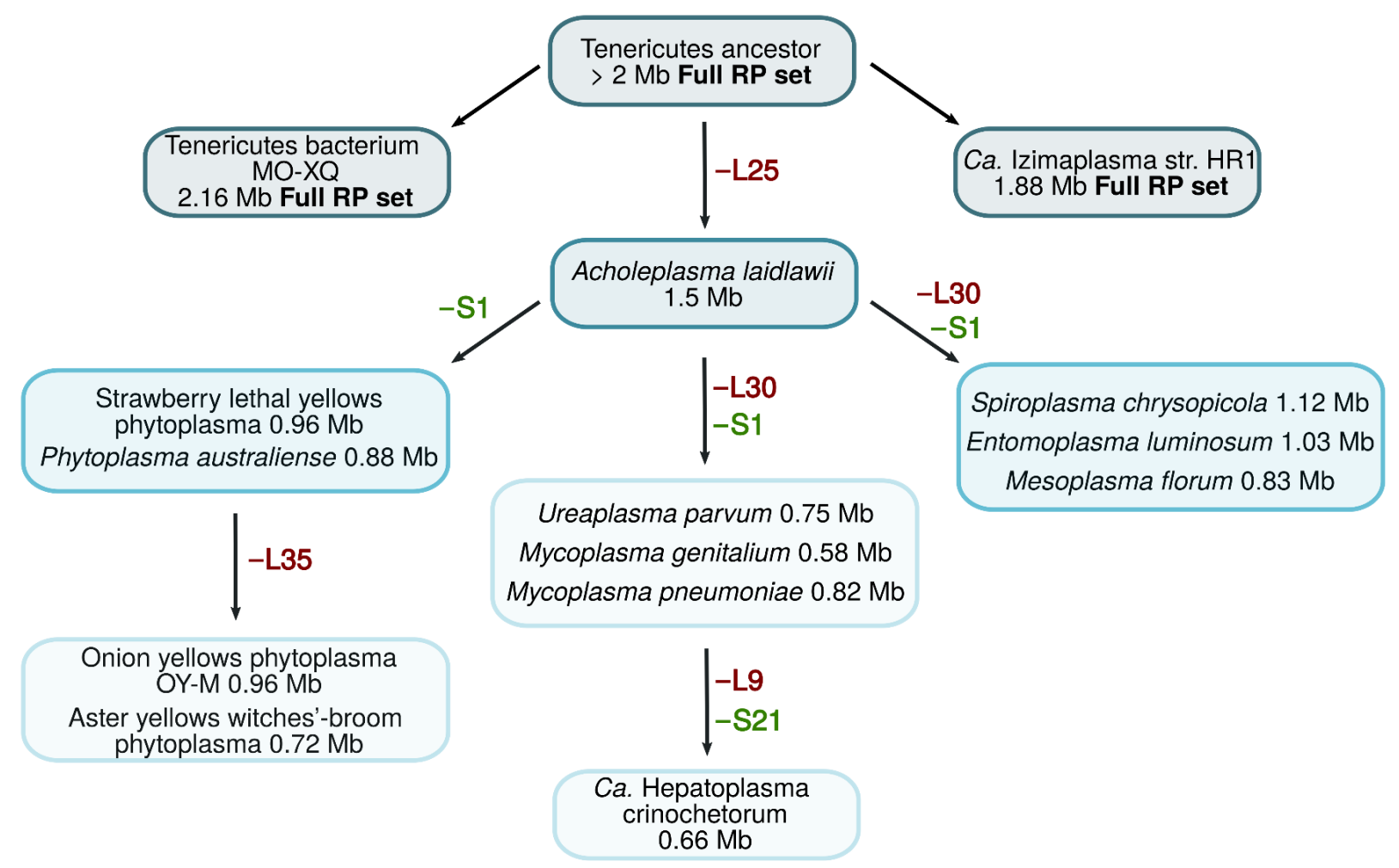

Fig. 3 